\title{
CORRIGENDUM
}

\section{EMX2 is epigenetically silenced and suppresses growth in human lung cancer}

J Okamoto, T Hirata, Z Chen, H-M Zhou, I Mikami, H Li, A Yagui-Beltran, M Johansson, LM Coussens, G Clement, Y Shi, F Zhang, K Koizumi, K Shimizu, D Jablons and B He

Oncogene (2010) 29, 5976; doi:10.1038/onc.2010.450

Correction to: Oncogene (2010) 29, 5969-5975; doi:10.1038/ onc.2010.330; published online 9 August 2010

Since the publication of the above manuscript, the authors have identified an error in the author list; the name of the seventh author was presented incorrectly. The corrected author list is shown above. 